\title{
Space Pattern of Samudera Pasai Sultanate
}

\author{
Rinaldi Mirsa*, Muhammad, Eri Saputra, Izzati Farhana \\ Department of Architectural Engineering, Universitas Malikussaleh, Aceh, Indonesia \\ *Corresponding author E-mail: rinaldi@unimal.ac.id
}

Manuscript received 23 Feb 2021; revised 2 March. 2021; accepted 15 March 2021. Date of publication 2 April 2021

\begin{abstract}
Samudera Pasai is one of the Islamic Sultanates in Indonesia which appeared in the Middle Ages or around 1267 AD. Evidence of the existence of the Sultanate of Samuedra Pasai in Indonesia is listed in the book Rihlah ilal-Masyriq (Wanderings to the East) written by Abu Abdullah Ibnu Batutha (1304 - 1368 AD), a Muslim adventurer who traveled to Samudera Pasai in 1345 AD. The spatial pattern of the Samudera Pasai Sultanate is no longer visible because there are no traces of archaeological remains in the form of any remaining buildings, except for the tombs of Sultanate figures and historical records of foreign adventurers who have explored the Samudera Pasai Sultanate. This record strengthens the evidence of the existence of the Samudera Pasai Sultanate. The methodology used in this case is a phenomenological approach and a historical approach, which are expected to approach optimal results in uncovering spatial patterns in the development of Islam. The spatial arrangement of the sultanate generally used the concept of catur gatra tungga, which was arranged in the form of: alun-alun (the square) as the center of space, markets to the north of the square, palaces to the south of the square, and mosques to the west of the square. The spatial arrangement then formed a spatial pattern that became the center of the Samudera Pasai Sultanate.
\end{abstract}

Keywords: Spatial Pattern, Catur Gatra Tunggal, Samudera Pasai Sultanate.

\section{Introduction}

Currently, Samudera Pasai Sultanate has no archaeological remains in the form of sultanate buildings, settlements, or housing, except for the tombs of the leaders of the Samudera Pasai Sultanate. Apart from the tomb, the relics that can be used as evidence of the existence of the Samudera Pasai Sultanate are historical records of the adventurers who had visited this area. The strongest evidence is the existence of the tomb of Sultan Malikussaleh who was the first king in the Samudera Pasai Sultanate. Another discovery that can also be used as evidence of the existence of the Samudera Pasai Sultanate is the discovery of artifacts in the form of exchange (currency) dirhams around the tomb[1]. The Samudera Pasai Sultanate was founded by Sultan Malik As-Saleh. This is evidenced by the discovery of the remains of a tomb belonging to Sultan Malik As-Saleh which is located in desa (villlage) Beuringen, Kecamatan Samudera. Sultan Malik As-Saleh died in the month of Ramadan in $679 \mathrm{AH}$ to coincide with $1297 \mathrm{AD}[2]$ [3].

Because the spatial pattern of Samudra Pasai Sultanate is no longer visible, research on the spatial pattern of Samudera Pasai Sultanate is very interesting to be studied further. This research was conducted to reveal the pattern of sultanate space that had developed in the central area of the Samudera Pasai Sultanate at that time [4].

\section{Literature Review}

\subsection{Space Pattern}

The spatial pattern is defined as the distribution of spatial use in an area which includes space allocation for protection functions and spatial designation for cultivation functions [5]. Space is a container covering land, sea and air, as a unitary area, where humans and other living creatures live in carrying out activities and maintaining their survival [6] [7].

Antoniou mentioned that Islamic cities in general concentrate a mosque as its central point. The category of Islamic cities in Indonesia is classified into 2 (two) groups; 1) cities as centers of commerce, and 2) cities that became the capital or centers of the sultanates such as Banten, Cirebon, Ternate, and also Pasai. The main characteristic of the central cities of the sultanate is the existence of the keraton (palace) as the city center. For example, the palace in Banda Aceh Darussalam was founded by Ali Mugghayatsyah in the middle of the 16th century AD. Facing north and in front of it is a large square. To the west of the square there is a grand mosque and to the east of the square there 
is a market. Around the palace there are several clusters for the Sultanate apparatus, such as aristocrats (knights), religious leaders (kefakihan / kauman), and also villages for foreigners such as the Pekojan village for the Koja (Gujarat) and Chinatown for the Chinese [8].

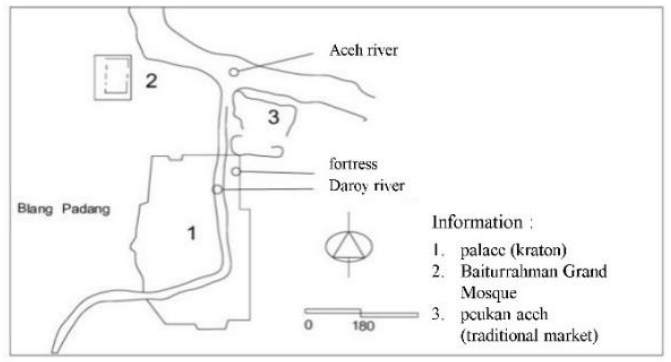

Fig 1. Map (Without Scale) Structure of Banda Aceh City in 1620 - 1640.

Source: Oetomo and Surachman, 2012

Both Nicolaus de Graff, who traveled to Aceh in 1641, and Dampier, who arrived in 1688, stated that apart from the palace as the center of power, there was also a mosque which was a center of worship, a market as a trade center and a village area. Market actors include traveling traders and local traders. Traveling traders generally came from foreign traders who sometimes settled and formed villages within the city. The houses were built using bamboo poles with a height of about 120-180 $\mathrm{cm}$ [9] [10] [11].

\subsection{Samudera Pasai Sultanate}

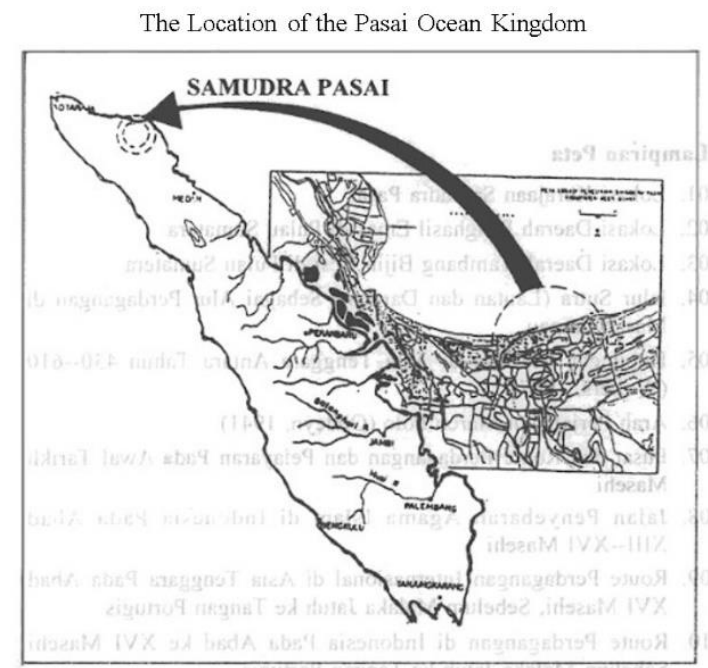

Fig 2. Location of the Samudera Pasai Sultanate Source: Ismail, 1997

Samudera Pasai is currently only in the form of a village (gampong), located approximately $15 \mathrm{~km}$ from the east of Lhokseumawe City [12], once the center of the sultanate for about three centuries, between the 13th century AD until the early 16th century AD. The spread of Islam in Samudera Pasai to various regions is closely related to shipping and trade activities. The growth and development of government politics with shipping and trade in the Sultanate of Samudera Pasai was caused by geographical factors located on the coast of the Malacca Strait which had been a route for international trade shipping long ago[13].

\subsection{The Concept of Catur Gatra Tunggal}

Catur Gatra Tunggal is taken from the Javanese language "catur" and "gatra". Catur means four and gatra means pillar or building. Catur gatra tunggal is defined as four elements in one unit and the square as the center. In Javanese philosophy, 4 places become a unity that must exist in a city: the square in the east, the market in the north, the mosque in the west, and the palace in the south[14] [15].

In terminology, catur gatra is defined as the spatial concept of the Islamic Sultanate on the island of Java which contains four pillars of life; economy, socio-culture, politics and religion, which are manifested in the form of buildings including markets, squares, palaces and mosques [16]. 


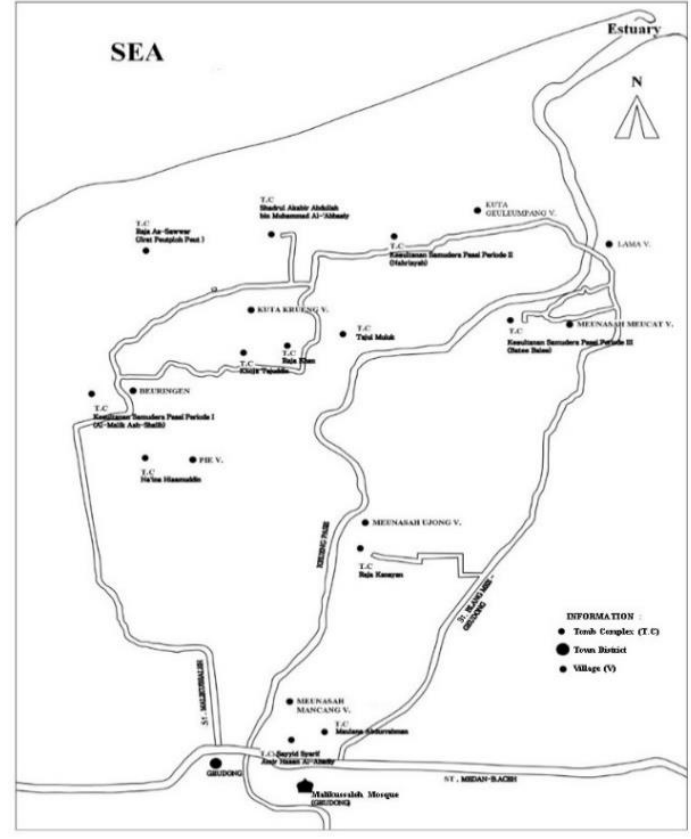

Fig 3. Oceanic Pasai Core Area

Source: Muhammad, 2015

\section{Methods}

Qualitative research is a scientific study that is used to examine the conditions of natural objects, where the researcher is the key instrument [17] [18]. In this study, researchers combined two methods; historical and phenomenological, to get the pattern of the sultanate space, but this research emphasizes the main method in the form of historical studies. The historical method examines the meaning or meaning of events or circumstances in the past by deepening the experiences of the subjects studied [19] and phenomenology serves to support the main method by observing events or phenomena through experiences from the point of view of the first person who experienced it. The purpose of combining the two methods is to find the meaning of past events based on the events or phenomena experienced from the first person perspective [20].

This research data is sourced from data in the form of documents and artifacts that can still be found as well as the landscapes found in their current location. Data are classified according to type bellow:

a. The documents include historical books, ancient manuscripts, including inscriptions on the past.

b. Compilation of notes and travel news for foreign adventurers who stop by or on purpose to visit Samudera Pasai.

c. The Samudera Pasai document is in the form of legacy images of building elements that are still there and aerial portraits of the Samudera Pasai region.

d. Artifacts are archaeological remains in the form of physical elements of buildings and spaces in the Samudera Pasai area, and archaeological maps from the asylum office.

e. Historical and ancient relics are the main reference.

f. Landscapes with all geographical, physical, and spatial or spatial aspects, the remains of natural elements that were once the environment of Samudera Pasai city at that time.

This research is supported by 3 (three) kinds of data or data sources: 1) primary sources, 2) secondary sources, and 3) tertiary sources. The subjects in the study were local people around ancient tombs and historical researchers of Samudera Pasai. The object of research studied is the area of ancient tomb sites, Kecamatan Samudera, North Aceh.

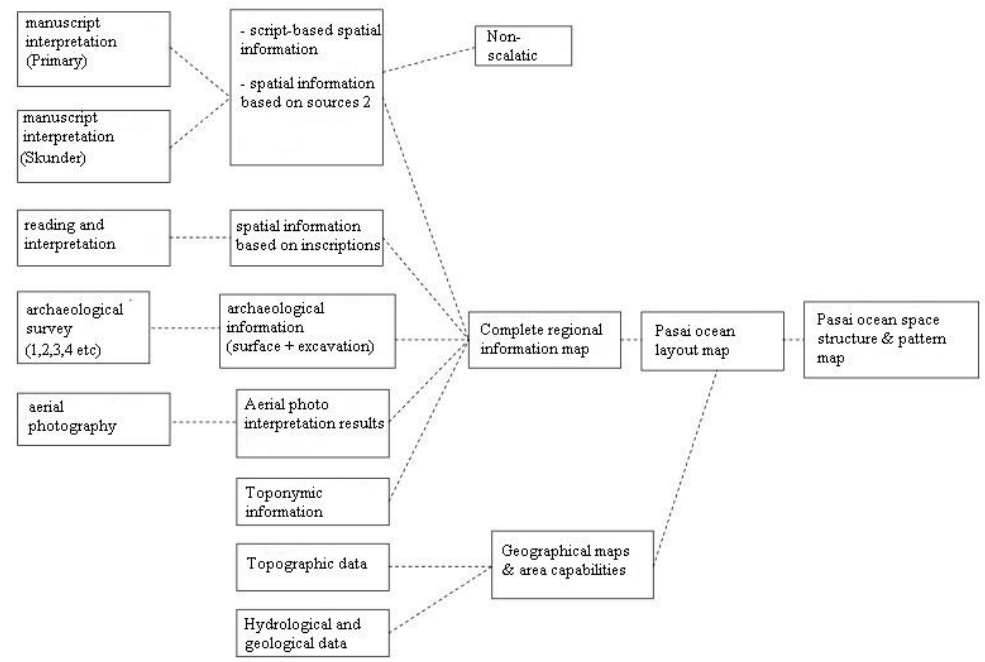

Fig 4. Steps for Reconstruction of the Spatial Plan for the Samudera Pasai Sultanate Source: Hermanislamet, 1996 


\section{Results and Discussion}

\subsection{The Archaeological Heritage of Samudera Pasai}

The distribution of archaeological remains is evidence of human occupation and the activities they carried out, which are assumed to be the embodiment of past human ideas and actions. Based on archaeological studies and historical data (including foreign news), the assumption is that Samudera Pasai, a port city on the East Coast of Sumatra, is an important port for goods, services and human activities on a regional and international scale. Pasai Ocean has developed very closely related to situational conditions, starting from the increasing number of oceans in the Indian Ocean and the Strait of Malacca on the shipping / trade routes of West Asia to China, the socialization process of Islam to the growth of political centers in the capital to the two edges of the Malacca Strait.

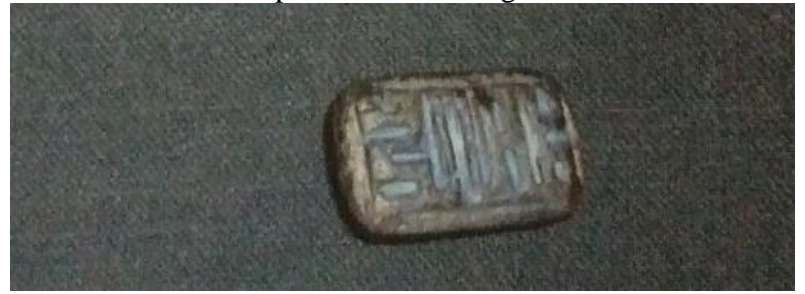

Fig 5. Seals during the Sultanate of Samudera Pasai Source: Muhammad, 2015

Sultan Muhammad's seal was found by Erwin, a resident of Kuta Krueng (Kuta Karang) Samudera, North Aceh, in December 2008. The location of the discovery is in one of the embankments of a fish pond, about 500 meters from the shoreline, and to the west of the Shadr Al- grave complex. Akabir 'Abdullah bin Muhammad, approximately 50 meters. When the seal was found, it was in a layer of soil surface that had been repeatedly stirred.

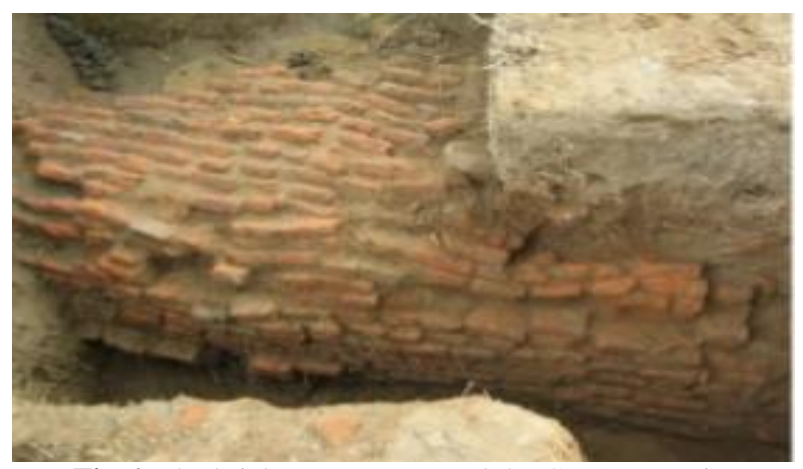

Fig 6. The brick structure around the Cot Astana site Source: Oetomo dan Surachman, 2012

The excavated brick composition is the remaining structure of the building. From measurements in two corners (southwest and northwest), it is estimated that the size of the building area is $35 \mathrm{x} 35$ meters. This is different from the initial measurements made of brick debris, which generally collapsed to the outside due to the pressure of the soil inside. The structure of the building is likely to collapse at the top due to soil pressure, while at the bottom it is held back by the soil layer on the outside. In general, the condition of the stacking brick is as mentioned above[9].

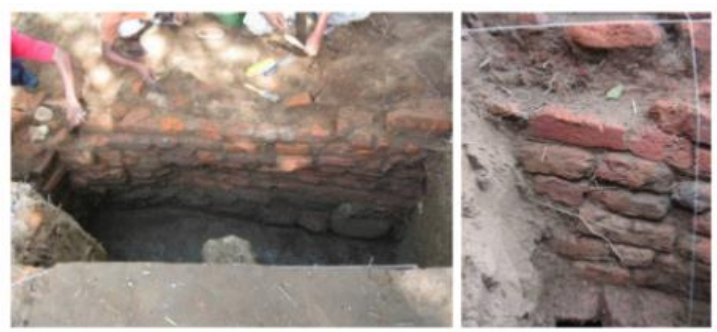

Fig 7. The remains of the excavated building structure Source: Oetomo dan Surachman, 2012

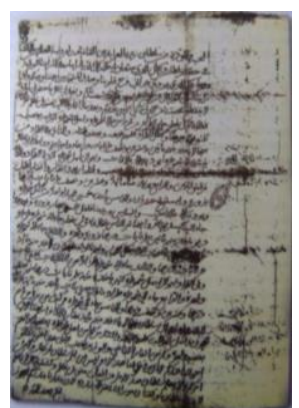

Fig 8. Manuscript of the Samudera Pasai Sultanate Source: Muhammad, 2015 


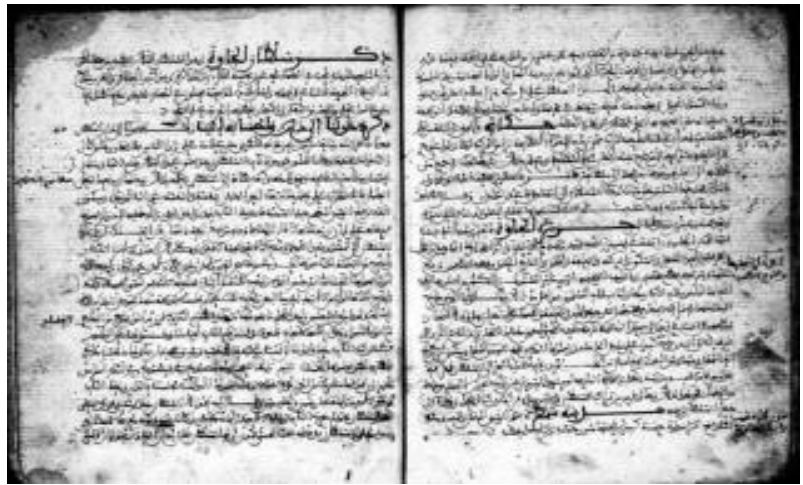

Figure 9: Manuscript of the Samudera Pasai Sultanate Source: Muhammad, 2015.

The findings of the Sultanate of Samudera Pasai which, on average, are at a depth of $60 \mathrm{~cm}$ from the surface, proving that the occupation of this site is not that deep. The findings of walls, foundations, ceramics as commodity items originating from various countries such as Thailand, China, Myanmar, Vietnam, the Netherlands and Europe prove that the Pacific Ocean as a trading center at that time had international relations with various countries.

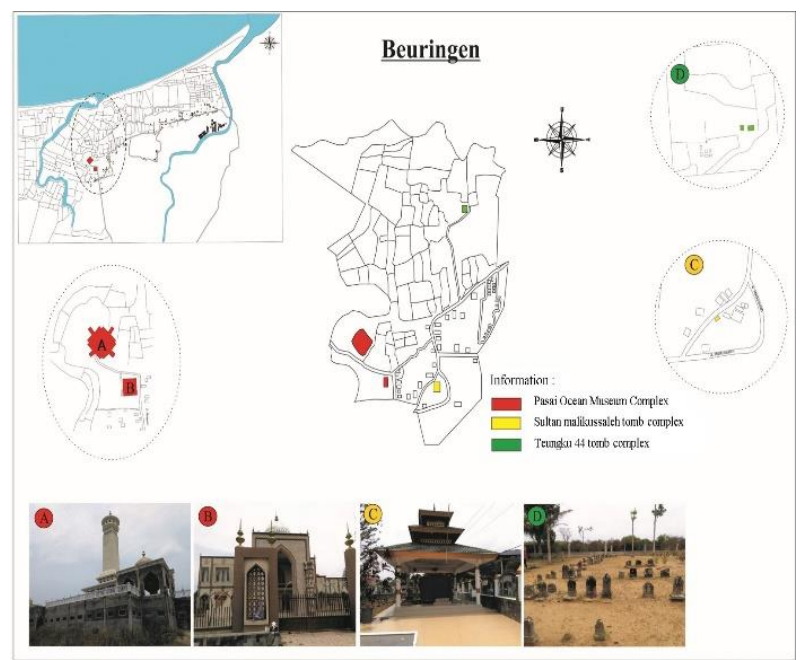

Fig 10. Mapping of Desa Beuringen

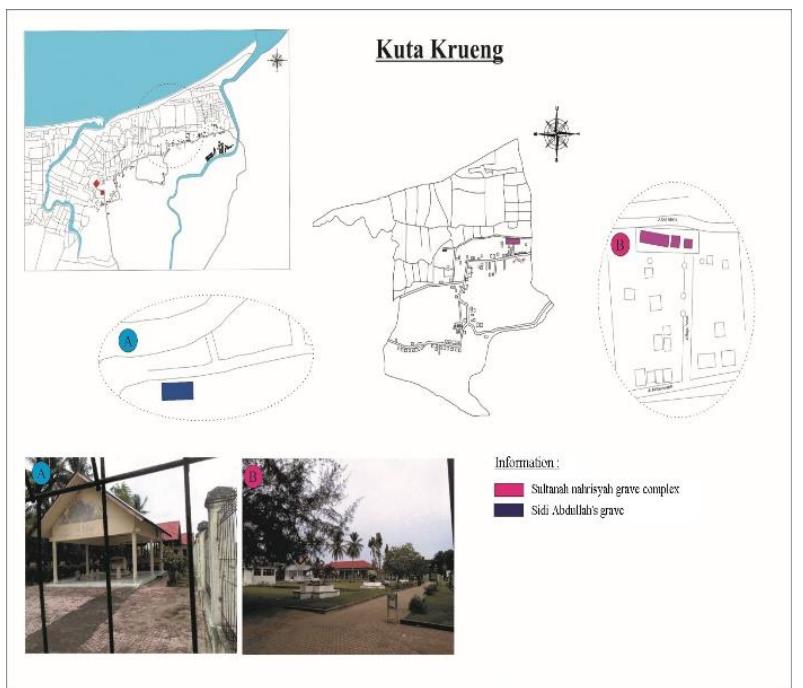

Fig 11. Mapping of Desa Kuta Krueng 


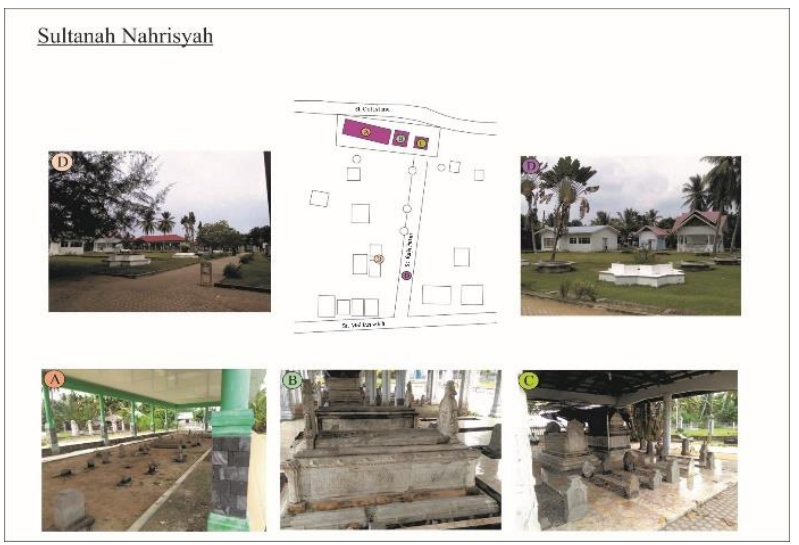

Fig 12. Mapping of Sultan Malikussaleh Tomb Complex

\subsection{Space Analysis}

The division of spatial analysis is classified into two parts, including:

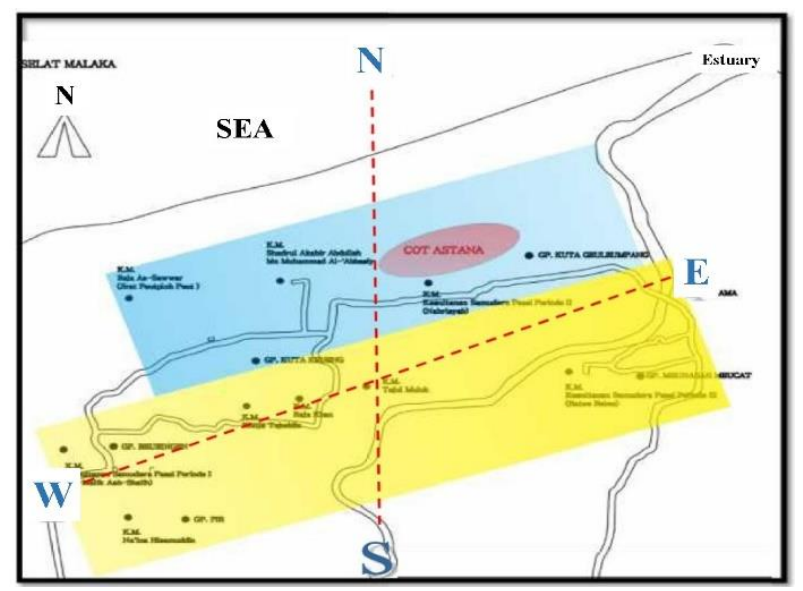

Fig 13. Division of site sectors for the Samudera Pasai Sultanate

a. The northern sector or the front sector is the sector closest to the beach, right on the beach in front of the Strait of Malacca, which is the sector occupied by the concentration of shards of foreign pottery and ceramics. The tomb complex which is divided into groups is the tomb complex of Sultanah Nahrisyah. A plot of land $1.65 \mathrm{~m}$ above sea level (asl) is called Cot Astana. Cot Astana is in a straight line, respectively from east to west. Each component occupies a certain space.

b. The southern sector is occupied by the tomb complex of Malik As-Shaleh, the tomb complex of Tajul Muluk Abdul Karim Muhammad, and the tomb complex of Sayid Syarif. If you observe its location from the west to the east, the westernmost boundary of the site of the former Sultanate of Samudera Pasai is the Al-Shaleh Tomb while the easternmost boundary is the Sungai Pase (Pase River).

\subsubsection{Alleged Palace and Square.}

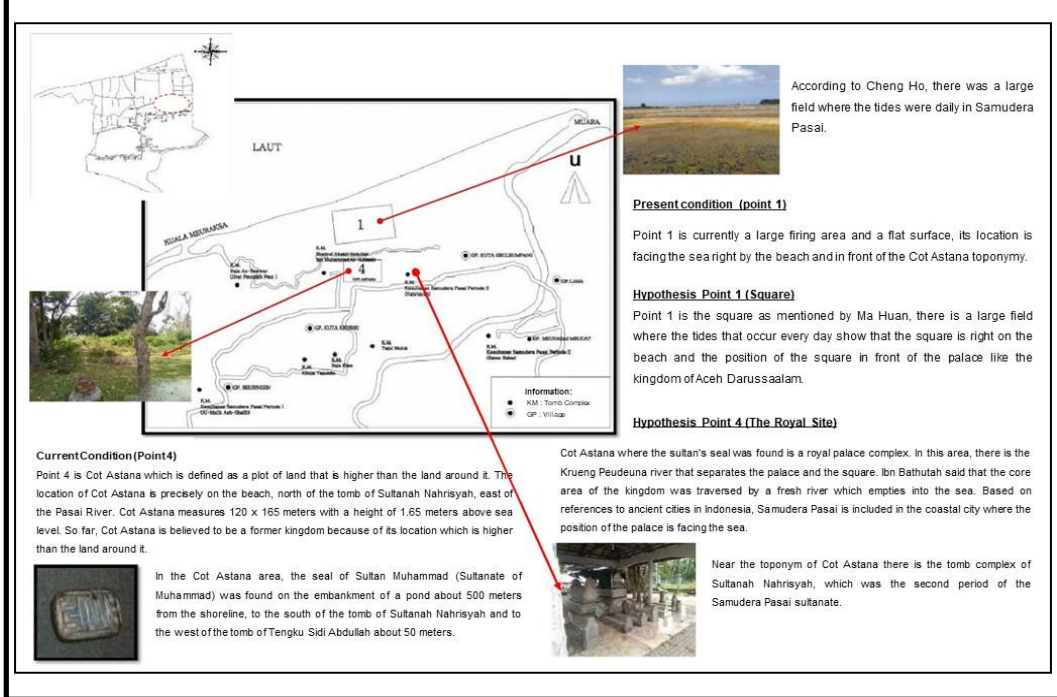

Fig 14. Alleged Palace and Square 


\subsubsection{Alleged Mosque}

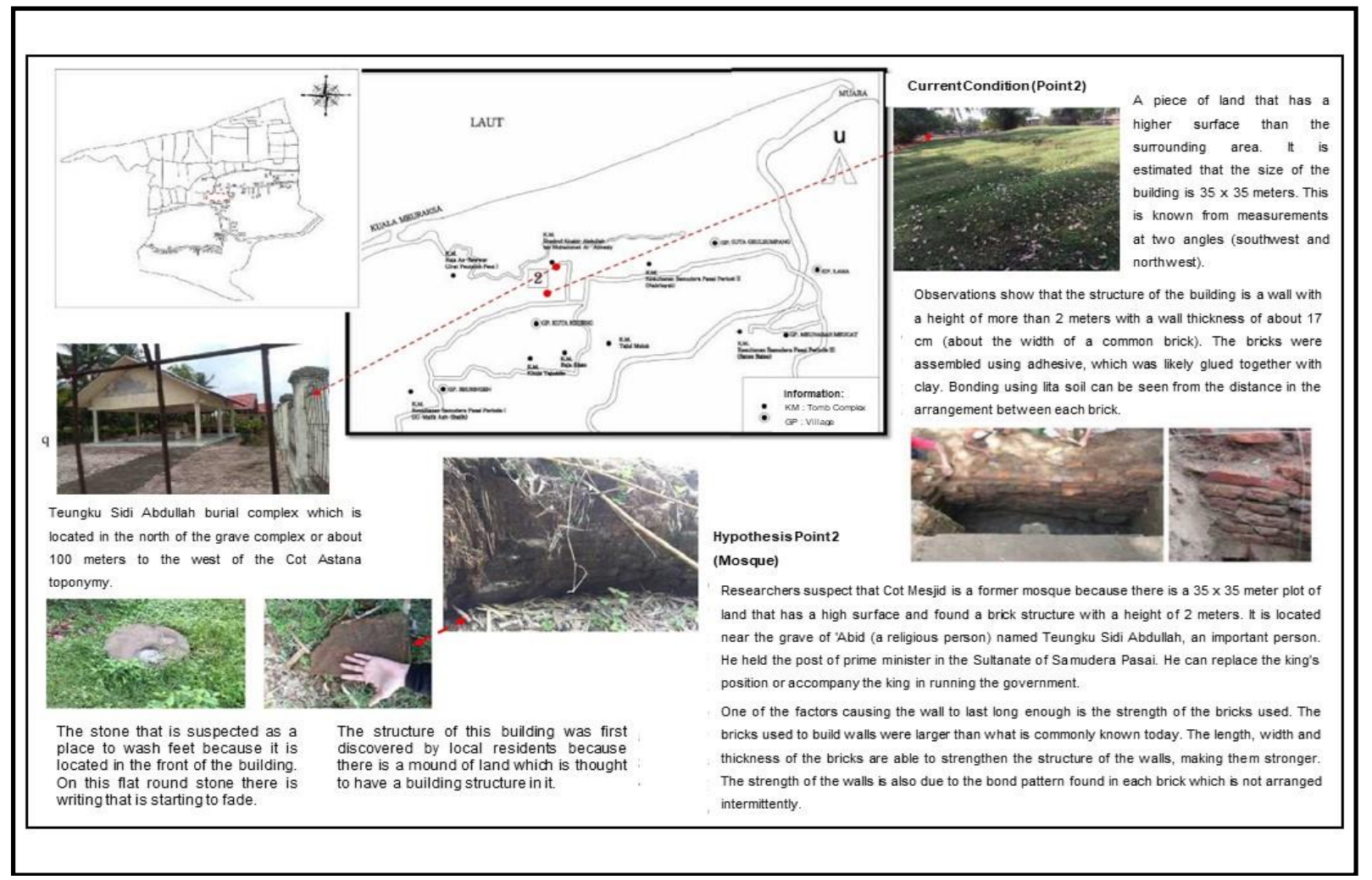

Fig 15. Alleged Mosque

\subsubsection{Alleged Market}

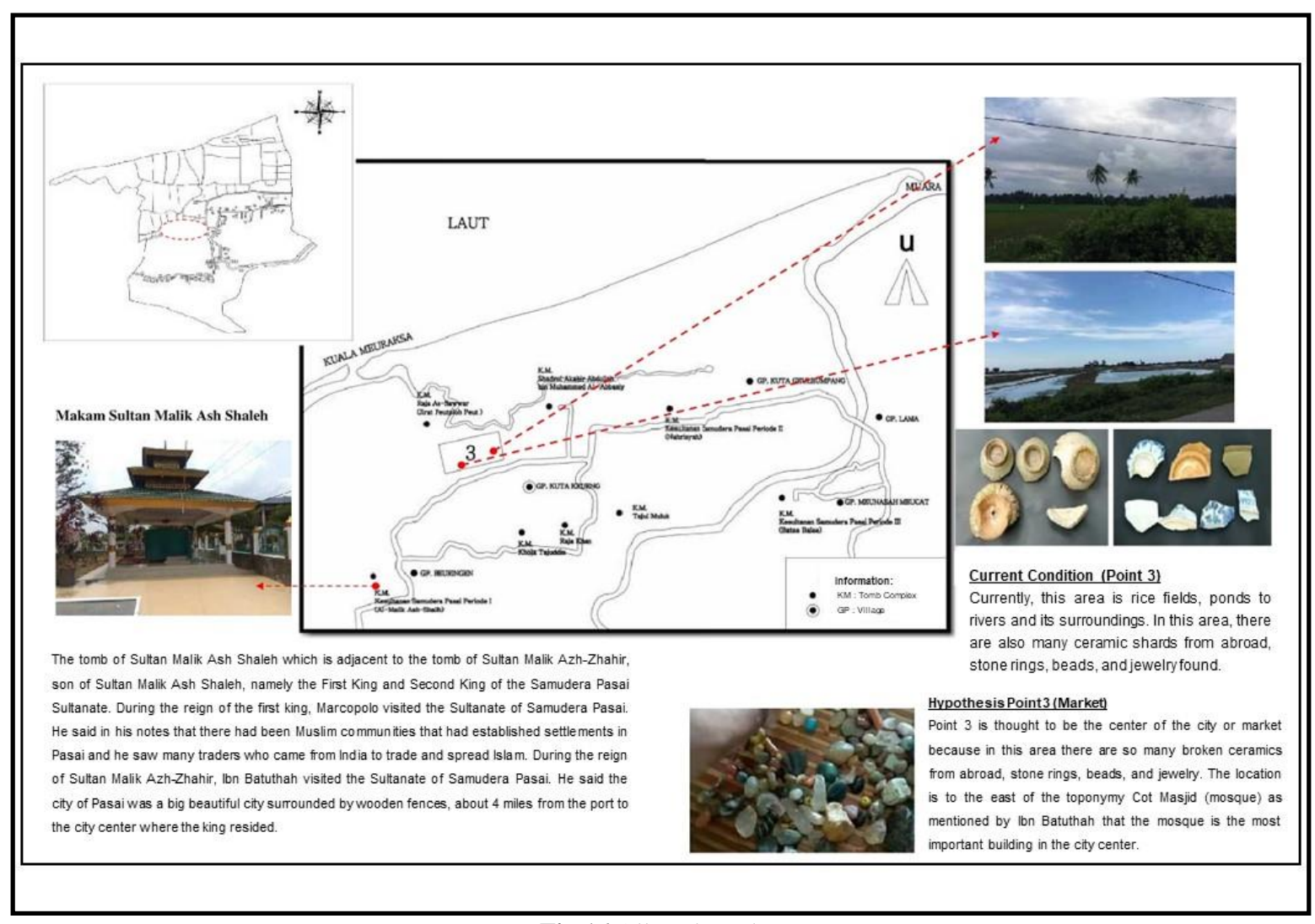

Fig 16.Alleged Market 


\subsubsection{Alleged Resettlement}

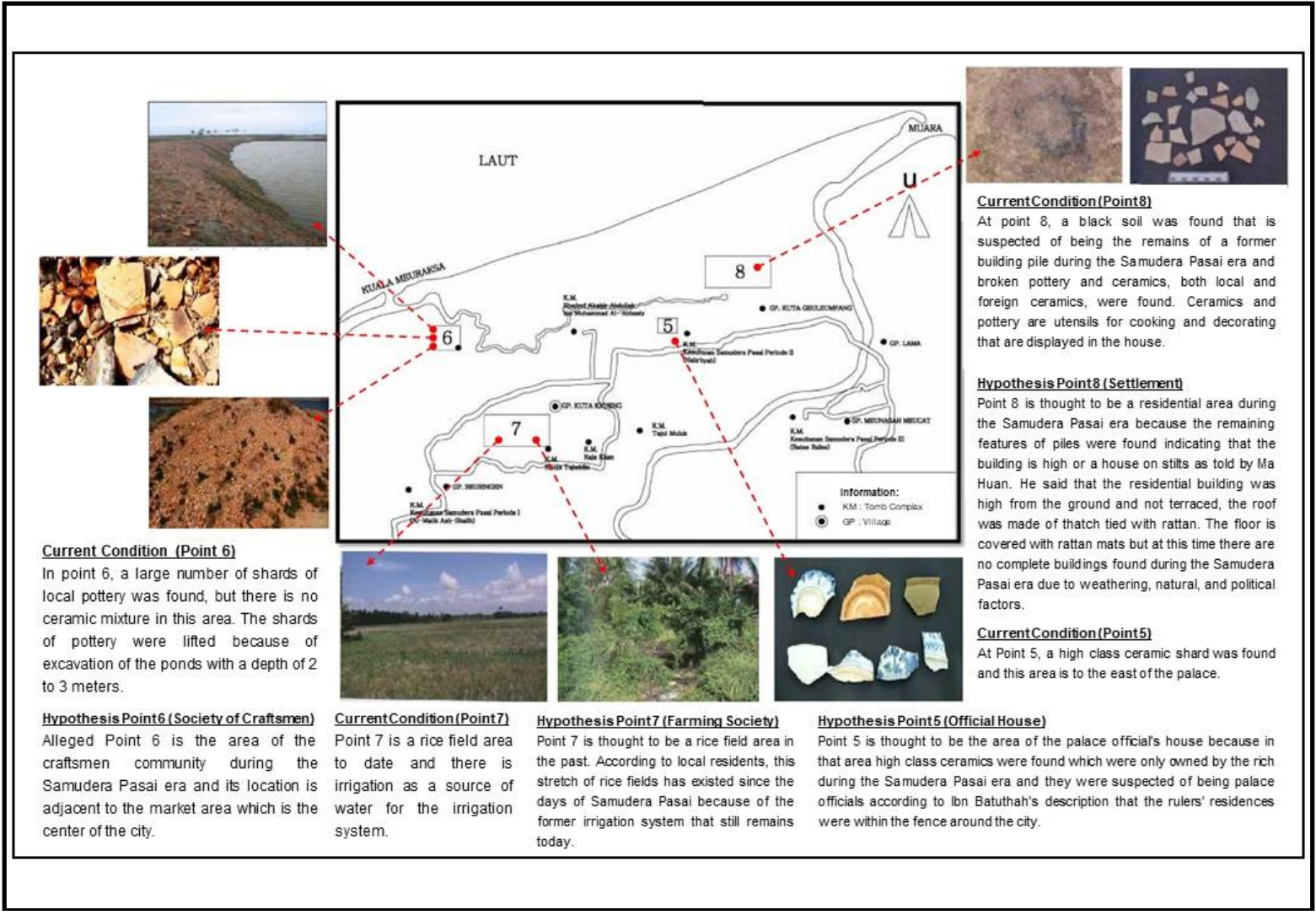

Fig 17. Alleged Settlements.

\subsubsection{Alleged Spatial Patterns Formed}

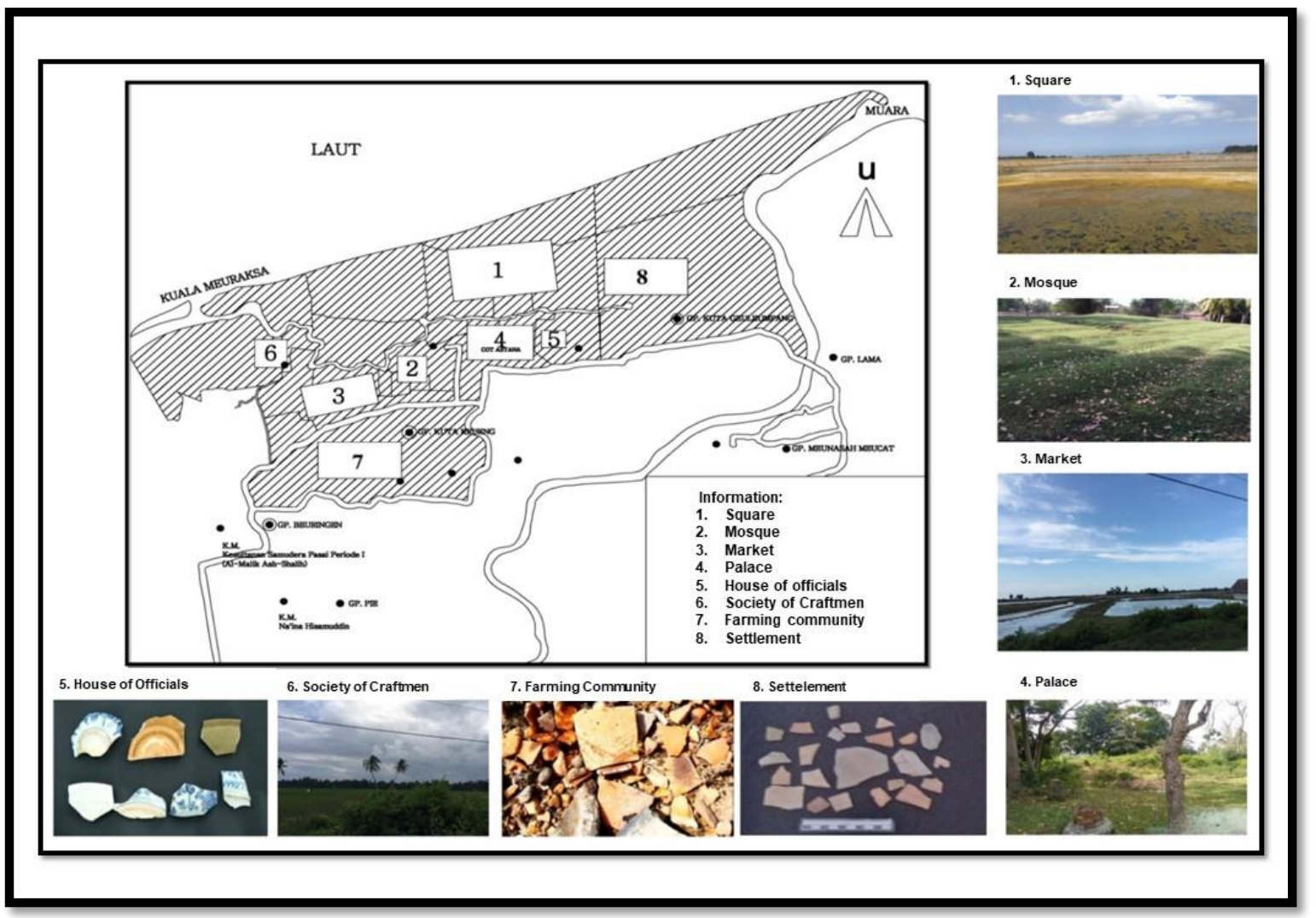

Fig 18. The spatial pattern of the Samudera Pasai Sultanate 
Based on catur gatra tunggal, the pattern of the sultanate space is divided into 4 (four) pillars of life: 1) economy, 2) socio-cultural, 3) political, and 4) manifested in the form of market buildings, squares, palaces, and mosques. The details are elaborated as follows:

1. The market as catur gatra in the economic field is used as a meeting place for humans to meet economic needs.

2. The plaza as catur gatra in the socio-cultural field was used as a gathering place for the people to meet their king.

3. The palace as catur gatra in the political field was used as the residence of the king to regulate the government.

4. The mosque as catur gatra in the religious field is used as a place for worship.

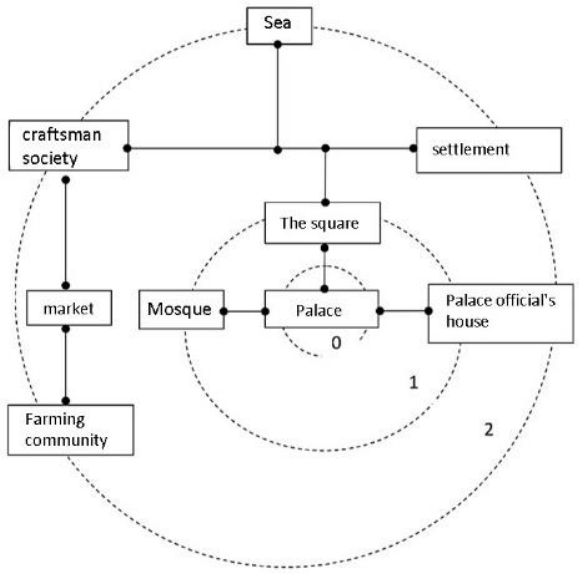

Fig 19. The spatial circle of the Samudera Pasai Sultanate

Information:

$0=$ Palace, $1=$ Royal Site, dan $2=$ State

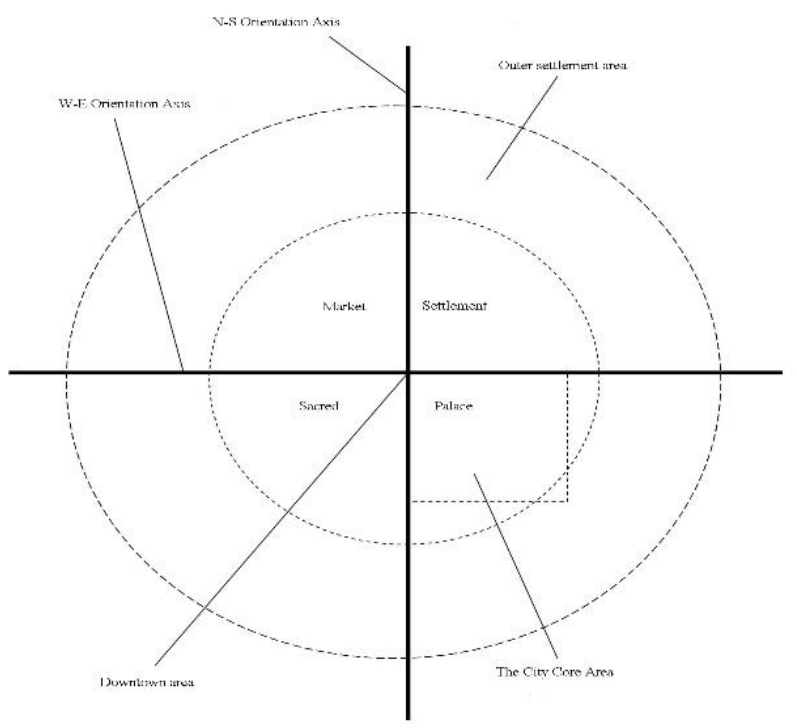

Fig 20. The Model Chart of the Samudera Pasai Sultanate

\section{Conclusion}

The Sultanate of Samudera Pasai is a former capital city of the past which has now changed its function to a village. The city of Pasai is the seat of government for the kings of Pasai. In the middle of the area there is a core area which is occupied by the sultan as a palace. The palace is fenced with a barrier that distinguishes the sultan's palace area from the market area where other trading activities take place. Based on this fact, it is stated that Pasai, which has a large city, is inhabited by residents who are scattered inland. The urban spatial system in Pasai can be seen from the foreign sailors who stopped in Banda Aceh in the pre-colonial era who were culturally similar to a time span that was not too far apart. The most likely approach is to find information on the spatial system of the Sultanate of Samudera Pasai. One of the information obtained from Beaulieu states that the most striking building is the palace, around the palace there are villages, grand mosques and markets. Its characteristics can be seen from the description below:

1. There is a port port as a center for international trade.

2. There is a large rock jutting out into the sea which is used as a natural defensive fortress.

3. There is a large field where the tide recedes every day. The waves in the estuary were very high and ships were constantly being spotted here.

4. Within the city were the residences of other rulers and nobles who were protected by the people outside the fence.

5. There is a palace as the residence of the sultan and a mosque as the most important building for worship in the city center.

6. The people of Samudera Pasai are followers of the Islamic religion. 
7. In its time, Pasai City was the most important city on the entire island of Sumatra.

8. The city of Pasai is estimated to have a population of no less than 20,000 people.

9. Housing residents are built higher than the ground and not terraced, the roof is made of palm leaves and thatch tied with rattan. The floor of the building is covered with rattan mats.

10. There is Cot Astana on the way from Samudera Pasai to the funeral of the kings of Kuta Karang.

11. Samudera Pasai is a coastal city due to the position of the palace facing the sea.

\section{References}

[1] Kusmiati, Catatan Sementara Tentang Mata Uang Samudra Pasai. Proyek Penelitian dan Penggalian Purbakala Departemen Pendidikan dan Kebudayaan. Jakarta, 1977.

[2] M. Said, Aceh Sepanjang Abad. Medan: PT Percetakan dan Penerbitan Waspada, 1981.

[3] I. G. Dharma Utamayasa, "Efect Physical Activity and Nutrition During The Covid-19 Pandemic," Int. J. Eng. Sci. Inf. Technol., vol. 1, no. 1, 2021, doi: 10.52088/ijesty.v1i1.58.

[4] S. Baqaruzi, A. Afit Miranto, and D. Wahyuda, "The Effect of Halbach Array Configuration on Permanent-Magnet Synchronous Generator (PMSG) Outer-Runner,” Int. J. Eng. Sci. Inf. Technol., vol. 1, no. 2, 2021, doi: 10.52088/ijesty.v1i2.50.

[5] M. Akib, Jackson, Charles, and Dkk, "Hukum Konstitusi dan Penataan Ruang, Pusat Kajian Konstitusid dan Peraturan PerundangUndangan," in Fakultas Hukum Universitas Lampung, Bandar Lampung, 2013.

[6] M. W. Choirul Umam, F. Hardaningrum, and R. Durrotun Nasihien, "Analysis Of Traffic Accident Area On The Road In Gresik District Based On Geographic Information System,” Int. J. Eng. Sci. Inf. Technol., vol. 1, no. 2, 2021, doi: 10.52088/ijesty.v1i2.52.

[7] M. Ayung Tama, M. I. Setiawan, and S. Budi Wasono, "Analysis Of The Performance East Circle Road Of Sidoarjo," Int. J. Eng. Sci. Inf. Technol., vol. 1, no. 2, 2021, doi: 10.52088/ijesty.v1i2.53.

[8] J. Antoniou, Menyelamatkan Kota-Kota Islam. Jakarta, 1999.

[9] W. Oetomo Repelita, Surachman, and Heddy, "Sisa Struktur Bangunan di Samudera Pasai, Tinjauan Konstruksi dan Fungsinya," Pus. Penelit. dan Pengemb. Arkeol. Nas., vol. XV, pp. 142-154, 2012.

[10] Z. Zakiyuddin and F. Reynaldi, "The Phenomenon of 'Badapu' Tradition with Nutritional Status in Postpartum Mothers in West Aceh,” Int. J. Eng. Sci. Inf. Technol., vol. 1, no. 1, 2021, doi: 10.52088/ijesty.v1i1.42.

[11] M. S. Arif, R. Durrotun Nasihien, and H. Sutowijoyo, "BIM Implementation in Mall Laves Project Construction Surabaya," Int. J. Eng. Sci. Inf. Technol., vol. 1, no. 2, 2021, doi: 10.52088/ijesty.v1i2.49.

[12] S. Darmiatun and D. Tasrial, "PRINSIP-PRINSIP K3LH: Keselamatan dan kesehatan Kerja, dan Lingkungan Hidup," Gunung Samudera, 2015. .

[13] H. M. Ambary, Tinggalan Arkeologi Samudra Pasai." Pasai Kota Pelabuhan Jalan Sutra Kumpulan Makalah Diskusi”. Jakarta, 1997.

[14] S. Kostof, The City Assembled The Elements of Urban Form Through History. London, 1992.

[15] Hartono, E. Ongko, and D. Abdullah, "HFLTS-DEA model for benchmarking qualitative data," Int. J. Adv. Soft Comput. its Appl., vol. 11, no. 2, 2019.

[16] M. Mahfut, M. V. Treesya Panjaitan, S. Wahyuningsih, T. Tripeni Handayani, and S. Sukimin, "Identification of Disease and Efforts to Protect Natural Orchid Plants Against Fungi Infection in the Liwa Botanical Garden," Int. J. Eng. Sci. Inf. Technol., vol. 1, no. 1, 2021, doi: 10.52088/ijesty.v1i1.39.

[17] D. Kearifan et al., "Civic Culture Dalam Nilai-Nilai Budaya," ejournal.undip.ac.id, 2016.

[18] D. Abdullah et al., "DEA Model with Hesitant Fuzzy Polyhedral Set in Benchmarking," in Journal of Physics: Conference Series, 2019, vol. 1361, no. 1, doi: 10.1088/1742-6596/1361/1/012033.

[19] J. W. Cresswell, "Research Design, Qualitative \& Quantitative Approaches, Thousand Oaks," in Thousand Oaks, California, 1994.

[20] M. F. Firmansyah and H. Z. Maulana, "Empirical Study of E-Learning on Financial Literacy and Lifestyle : A Millenial Urban Generations Cased Study,” Int. J. Eng. Sci. Inf. Technol., vol. 1, no. 3, pp. 75-81, 2021. 